\title{
RECENT LITERATURE
}

Specht, R. L., R. Rayson and M. E. Lackman, 1958 - Dark Island Heath (Ninety-Mile plain, South Australia). VI. Pyric succession: Changes in composition, coverage, dry weight, and mineral nutrient status. Austral. J. Bot., 6, I, 59-88

SwINDALE, D. N. and I. T. CurTis, 1957 - Phytosociology of the larger submerged plants in Wisconsin lakes. Ecology $38,3,397-407$.

TaCiK ,T., M. Zajacowna \& K. ZarzyCKI, I957- Geobotanisches aus dem Beskid Niski-Zuge im mittleren Teile der Karpaten. Act. Soc. Bot. Poloniae 26, I I 7 -43.

VAN ZEIST, W., I955 - Pollen analytical investigations in the northern Netherlands. With special reference to archaeology. Acta Bot. Neerlandica 4, I, XV u. 8I p.

WATT, A. S., 1957 - The effect of excluding rabbits from grassland B (M e s o b r o m e t u m) in Breckland. Jour. Ecol. 45, p. 86r-78.

Westhoff, V. \& H. Passchier, t958 - Verspreiding en oecologie van Scheuchzeria palustris in Nederland, in het bijzonder in het Bestmerven bij Ommen. De Levende Natuur, 6r, 59-67.

WesthofF, V., 1958 - Verspreidingsoecologisch onderzoek van zeldzame planten. De levende Natuur, 61, 193-202.

- I 958 - De Waddenkusten in botanisch opzicht. Natura, 55, 5 p.

-, 1958 - De plantegroei van doodemanskisten eens en thans. Natura, 55, 4 p.

-, I958 - Boden- und Vegetationskartierung von Wald- und Forstgesellschaften im Quercion robori-petraea-Gebiet der Veluwe (Niederlande). Angewandte Pflanzensoziologie, $\mathrm{H}$. 15, 23-30.

YamanAKA, T., I957 - The Forest Vegetation of the Amami Islands with special reference to the Shiia Sieboldii Forest. Rep. USA Marine Biol. Stat. vol. 4 , no. 2.

ZARZYCKI, K., I958 - Humid meadows in the environs of Czernichow near Cracow deserving protection. Ochrony Przyrody R. 25, p. 49-69.

\section{NEWS OF THE ASSOCIATION}

We regret to inform you of the sudden death of Professor Alberto Chiarugi, Director of the Botanical Institute of Florence University, occured on february the 25 th in Florence. 